\title{
Генноинженерная бuоmехноловия
}

УДК $5 \%, 214.622$

(C) С. П. Коваленко, Н. ІІ. Мертвецов, 1990

\author{
ЭКСПРЕССИЯ В ESHERICHIA COLI ГEHA \\ АНГИОГЕНИНА ЧЕЛОВЕКА, ТРАНСЛЯЦИОННО СЛИТОГО \\ С N-КОНЦЕВЫМ ФРАГМЕНТОМ $\beta$-ГАЛАКТОЗИДАЗЫ
}

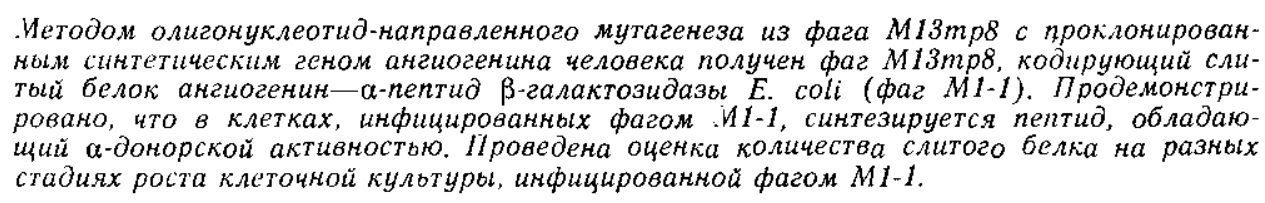

Введение. При получении генноннженерных продуцентов оценка уровня экспрессии гетерологичных генов в $E$. coli часто затруднена из-за сложности или даже отсутствия функциональных тестов, позволяющих опредилить количества целевого продукта в клетках. Один из возможных подходов к созданию универсальных систем оценки количества рекомбинантных белков - конструирование полипептидов, содержащих наряду с целевой аминокислотной последовательностью какой-либо дополнительный, легко тестируемый маркер. Таким маркером может служить, в частности, $\alpha$-пептид $\beta$-галактозидазы $E$. coli, способный к $\alpha$-комплементации с $\Delta M 15 \beta$-галактозидазой $E$. coli c формированием активного фермента. $\Delta M 15 \beta$-галактозидаза представляет собой белок, не обладающий $\beta$-галактозидазной активностью, в котором отсутствует $\mathrm{N}$-концевая аминокислотная последовательность нормальной $\beta$-галактозидазы E. coli. Такой белок формируется в клетках $E$. coli, несущих делецию $\Delta M 15 \mathrm{gal}$. При добавлении к раствору с $\Delta M 15 \beta$-галактозидазой полипептида с недостающей $\mathrm{N}$-концевой последовательностью $\beta$-галактозидазы формируется белок, обладающий $\beta$-галактозидазной активностью. При этом $N$-концевой пептид называют $\alpha$-донором, дефектную $\beta$-галактозидазу $-\alpha$-акцептором, а явление формирования белка с ферментативной активностью - $\alpha$-комплементацией [6].

a-Пеплид представляется удобным маркером для генноинженерных белков, поскольку, с одной стороны, в целом ряде широко распространенных векторов, например, серий $M 13, p U C, p T Z$ в непосредственной близости от клонированного фрагмента находится ген lac $Z^{\prime}$, кодирующий $\alpha$-пептид $\beta$-галактозидазы $E$. coli, a с другой - известен ряд примеров, где $\alpha$-пептид с полипептидными «довесками» самой разной природы обладал способностью к $\alpha$-комплементации. Так, $\alpha$-донорской активностью обладали слитые с $\alpha$-пептидом домены белка $A[1]$, белки фага $\varphi X 174$ [2], продукт гена $r p o C^{\prime}$ [3], $\alpha$-2-интерферон человека [4] и ряд других белков [5]. $\alpha$-Донорская активность тестируется довольно просто - достаточно в исследуемый образец добавить избыток $\Delta M 15 \beta$ галактозидазы (в виде грубого экстракта клеток $E$. coli штамма $J M 103)$ и измерить $\beta$-галактозидазную активность в исследуемом образце, которая будет прямо пропорциональна количеству $\alpha$-донора [6].

В данной работе описано конструирование единой трансляционной рамки гена апгиогенина человека с геном $\operatorname{lac}^{\prime}$ в фаге $M 13 m p 8$. Формирование такой трансляционной рамки приводит к появлению в $E$. co$i i$, инфицированной соответствующим фагом, белка, обладающего способностью к $\alpha$-комплементации $\Delta M 15 \beta$-галактозидазы $E$. coli. 
Материалы и методы. В работе использовали штамм E. coli JM103, бактериофаг MI3Анг [7], dNTP, ddNTP, изопропил- $\beta$ - $D$-тиогалактознд (ИПТГ), 5-броминдоксил-3- $\beta$ - $D$-галактопиранозид (Y-Gal), o-нитрофенилгалактознд (ОНФГ) производства НИКТИ БАВ (Бердск), фенилметилсульфонилфлуорид фирмы «Serva» (ФРГ), ДНҚазу I фирмы «Sigma» (США). Олигонуклеотиды синтезированы В. В. Горн (Ин-т биоорг. химин Сиб. отд-ния АН СССР, Новосибирск), как описано ранее [7].

Олигонуклеотид-направленный мутагенез проводили по [9], для анализа нуклеотидной последовательности также использовали метод, примененный в работе [9].

Для оценки количеств $\alpha$-комплементирующих белков в і.И1-1-инфицированных клетках $E$. coli ночную культуру $J M 103$ разводили средой ҮТ $Х 2$ [9] до $10^{8}$ клеток в 1 мл, добавляли фаг $M 1-1$ в соотношении $100: 1 ; 250: 1 ; 500: 1,30$ мин инкубировали при $37^{\circ} \mathrm{C}$, разводили средой $\mathrm{YT} \times 2$ в 10 раз, растили при встряхивании и $37^{\circ} \mathrm{C}$. Через 2 ч добавляли ИПТГ до 2 мМ, после чего отбирали аликвоты по 0,5 мл через каждые 30-60 мин. Аликвоты центрифугировали, клетки ресуспендировали в буфере, содержащем $0,1 \mathrm{M}$ трис- $\mathrm{HCl}, \mathrm{pH} 8,0 ; 0,2 \mathrm{M} \mathrm{NaCl}, 10 \mathrm{M}$ фенилметилсульфонилфлуорид, $10 \mathrm{~m} M$ 2-меркаптоэтанол, 0,5 мг/мл лизоцима, выдерживали 1 ч при $0^{\circ} \mathrm{C}$, добавляли тритон $\mathrm{X}-100$ до $0,1 \%, \mathrm{MgCl}_{2}$ до $2,7 \mathrm{mM}$, ДНКазу I до $0,1 \mathrm{мг} /$ мл. После 3 ч инкубации добавляли 0,5 мл буфера Z [11], 10-100 мкл экстракта клеток JM103, ОНФГ до 0,4 мг/мл. После инкубации 1-20 ฯ) образцы цснтрифугировали, измсряли оптичсскую плотность супернатанта при длине волны 420 нм. Активность $\beta$-галактозидазы рассчитыњали по [11].

Результаты и обсуждение. Ранее пами описал химико-ферментативный синтез гена ангиогенина человека [7]. В соответствии со схемой сборки и клонирования гена ангиогенина получен фаг М13Анг, в котором трансляционная рамка ангиогенина совпадает с рамкой $\alpha$-пептида $\beta$-галактозидазы фага $M 13 m p 8$, однако $\alpha$-пептид не экспрессируется в клетках, инфицированных $M 13$ Анг из-за наличия двух терминирующих кодонов в конце гена ангиогенина. Возможность замены этих терминирующих кодонов на кодоны для аспарагиновой кислоты и пролина позволяет получить фрагмент ДНК, кодируюший слитый белок ангиогенин - $\alpha$-пептид. Такой белок, предположительно, может служить эффективным $\alpha$-донором для $\Delta M 15 \beta$-галактозидазы, а значит и детектировать его будет довольно просто даже в незначительных количествах. Последовательность Asp-Pro, привносимая на место стыка полипептидов, соответствующих ангиогенину и $\alpha$-пептиду, предполагает вышепление ангиогенина из слитого белка с помошью мягкого кислотного гидролиза [8].

Замену терминирующих кодонов TAATGA на кодоны GATCCG осуществили с помощью олигонуклеотид-направленного мутагенеза [9]. Для этого 27-членный олигонуклеотид структуры CTTGGCTGCAGCGGATCTGGTCGACGG, а также унивсрсальный праймер для секвенирования структуры GTAAAACGACGGCCAGT отжигали с одноцепочечной ДНК фага М 13 Анг, вторую цепь гетеродуплекса достраивали большим фрагментом ДНК-полимеразы I $E$. coli, гетеродуплексами трансфицировали клетки E. coli $J M 103$. После трансфекции на индикаторном газоне $J M 103$ образовались 604 белые бляшки и 6 синих. В контрольном эксперименте (без мутагенизирующего олигонуклеотида) все блянки $\left(10^{4}\right)$ были белыми. Анализ первичной структуры ДНК фагов, размноженных из синих бляшек, показал, что замена пуклеотидов произошла в соответствии с запланированной схемой (рис. 1). ГІолученный фаг с заменой ТАATGA $\rightarrow$ GATCCG назвали $M 1-1$. Фаг $M 1-1$ формировал синие бляшки на индикаторном газоне E. coli JM103.

На электрофореграмме суммарных клеточных белков $E$. coli, инфи, цированных $M 1-1$, не удалось обнаружить полос, соолветствующих слитому белку, что свидетельствует о невысоком уровне экспрессии этого белка в $E$. coli. В то же время возможность оценить количество слитого белка ангиогенин — $\alpha$-пептид по тесту комплементации с $\Delta M 15 \beta$-галактозидазой позволяет рассмотреть изменение количества слитого белка в разных фазах роста клеточной культуры, инфицированной $M 1-1$. Как отмечалось выше, $\beta$-галактозидазная активность клеточных экстрактов, содержащих $\alpha$-донор, в условиях избытка $\Delta M 15 \beta$-галактозидазы отражает количество $\alpha$-комплементирующего белка. Результаты изме- 


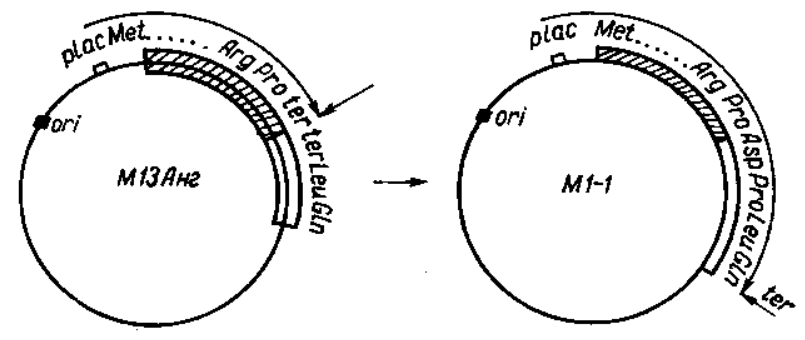

tac

$\operatorname{lac}^{+}$

Arg Pro ter ter Leu Gln

... ATC TTC CGT'CGA'CCA TAA TGA'CTG"CAG'CCA AGC'TTGGCA ... — DHK DAIA M13AHZ

GGCAGCTGGT 7 GACGTCGGTTC

$C$ AGGC,

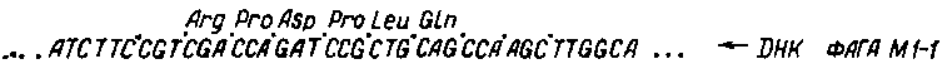

CAИGHИE ГEHA AHTHOTEHИHA C ГEHOM LOC $Z^{\prime}$

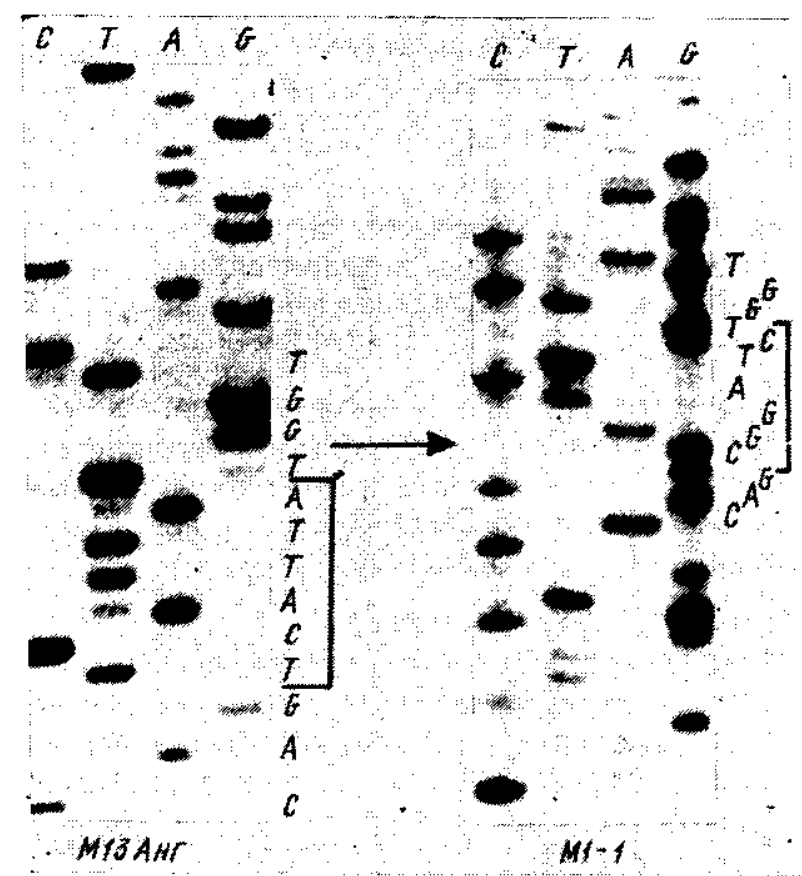

Рис. 1. Схема введения олигонуклсотид-направленной муташии в ДНК фага М13Анг для получения еднной трансляционной рамки ангиогенин-N-концевой фрагмент $\beta-г а-$ лактозидазы. Приведены фрагменты секвенирующего геля, демонстрирующие происшедшую замену

Fig. 1. Oligonucleotide-directed mutation was introduced in M $13 \mathrm{Ang}$ phage to obtain a single reading frame of angiogenin-N-terminal fragment of $\beta$-galactosidase. Fragments of sequencing gel are presented to demonstrate the mutation occured

рения активности $\beta$-галактозидазы в экстрактах клеток при добавлении нзбытков $\triangle M 15 \beta$-галактозндазы на разных стадиях роста клеточной культуры $E$. coli $J M 103$, инфицированной $M 1-1$, приведены на рис. $2, a$. Видно, что количества белка, способного быть $\alpha$-донором, возрастают 
с увеличением плотности культуры, а на ранних фазах роста $E$, coliс увеличением множественности инфекции фагом. Возрастание количества $\alpha$-донора в первые часы после индукции сменяется уменьшением (по-видимому, вследствие протеолиза) $\alpha$-комплементирующего белка в стационарной фазе роста. Увеличением множественности фага можно добиться некоторого повышения количества $\alpha$-донора на ранних этапах poста $E$. coli. Однако в целом количества исследуемого белка столь незначительны, что не обнаруживаются гель-электрофорезом суммарных
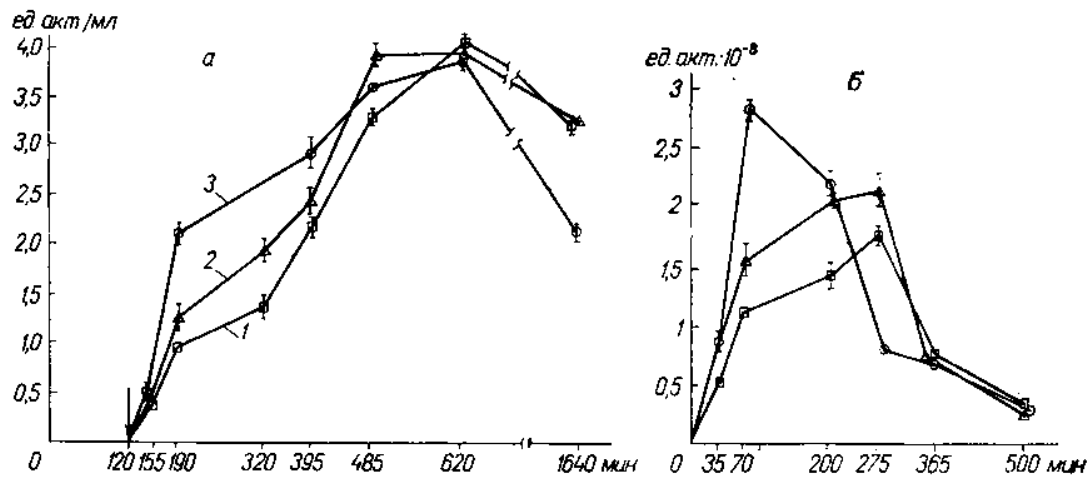

Рис. 2. Динамика изменения количества $\alpha$-комплсментирующих белков в $M /$ 1-инфицированной культуре $E$. coli при различной множественности заражения фагом $(a)$ и то же в пересчете на единичную клетку $E$. coli $(\sigma): a-$ по оси абсцисс - время от начала инфекции, стрелкой отмечено введение в среду индуктора lac-оперона ИПТГ; по оси ординат - активность $\beta$-галактозидазы в 1 мл клеточной суспензии в условиях избытка $\Delta M 15 \beta$-галактозндазы; 6 - по оси абсиисс - время после индукции lac-оперона; по оси ординат - то же, что $a$ в пересчете на единичную клетку. Множественность заражения фагом: $1-100 ; 2-250 ; 3-500$

Fig. 2. Dynamics of changes in the $\alpha$-complementary porteins amounts during the $M 1-1$ infected E. coli growtx. X axis-time after infection, induction of lac-operon by IPTG indicated by arrow. Y axis $-\beta$-galactosidase activity in $\mathrm{I} \mathrm{ml}$ of cell suspension in the excess of $\Lambda M 15 \beta$-galactosidase $(a)$; dynamics of changes in the $\alpha$-complementary proteins amounts per a single cell. $\mathrm{X}$ axis - time after lac-operon induction. $\mathrm{Y}$ axis - $\boldsymbol{\beta}$ galactosidase activity per a single cell in the $\Delta M 15 \beta$-galactosidase excess (6). Multiplicity of infection: $1-100,2-250,3-500$

белков $M 1-1$-инфицированной $E$. coli даже при оптимизации множественности заражения в момент максимального количества $\alpha$-донора в клетке (множественность заражения - 500, время после индукции 70 мин). Принимая во внимание, что в наиболее чистых препаратах $\beta$-галактозидазы $E$. coli удельная активность пе превышает 1000 ед. акт. на 1 мг белка [10], можно оценить и абсолютные количества белка с $\alpha$-донорской активностью в экстрактах $E$. coli, инфицированных фагом M1-1. Действительно, измеряемая активность $\beta$-галактозидазы через 4 ч после индукции составляет 1,8 ед. акт., что соответствует $\sim 1,8 \mathrm{мkr}$ $\beta$-галактозидазы. Учитывая, что молекулярная масса $\beta$-галактозидазы в 4,1 раза больше, чем слитого белка (ангиогенин- $\alpha$-пептид), при условии участия всех имеющихся молекул слитого белка в $\alpha$-комплементации, количество $\alpha$-донора можно оценить как $\sim 0,45$ мкг в 1 мл клеточной суспензии. Это составляет менее $0,1 \%$ суммарных белков клетки. Понятно, что такие количества слитого белка могут маскироваться другими белками на электрофореграммах суммарных клеточных лизатов.

Таким образом, используемая схема позволяет оценивать количества белка в клетке даже в том случае, когда отсутствуют методы его функциональной детекции, необходимые антитела недоступны, а электрофоретический анализ суммарных белков клетки не позволяет выявить этот белок из-за незначительных количеств. Введение сайта химического расщепления белка между полипептидами, соответствующими ангиогенину и $\alpha$-пептиду, предполагает возможность избавиться от маркера после очистки химерного белка. Несмотря на то, что об универсальности данной схемы говорить, по-вндимому, еще рано, $\alpha$-донор- 
ская активность $\alpha$-пептида, слитого с интерфероном [4], фрагментом белка $A[1]$, белком фага $\varphi X 174$ [2] и рядом других белков $[3,5]$, дает основание предположить достаточно широкие возможности применения использованной нами методологии для детекции самых различных прои эукариотических генноинженерных белков при экспрессии их в $E$. coli. Пример с ангиогенином, описанный в данной статье,- еще одно тому подтверждение. Оценка количества слитого белка в $M I-I$-инфицированных клетках показала, что сама по себе система $E$. coli/申ar $M 13$ с геном ангиогенин - $\alpha$-пептид под регуляцией lac-оперона дает незначительный уровень экспрессии, мало изменяющийся в процессе роста культуры и с варьированием множественности инфекции. Однако использование слитого белка ангиогенин $-\alpha$-пептид несомненно может значительно упростить выбор оптимальной системы экспрессии ангиогенина в $E$. coli.

EAPRESSION IN ESCHERICHIA COLI OF THE HUMAN ANGIOGENIN GENE TRANSLATIONALLY FUSED WITH THE N-TERMINAL FRAGMENT OF $\beta$-GALACTOSIDASE

\section{S. P. Kovalenko, N. P. Mertuetsov}

Institute of Binorganic Chemistry,

Siberian Branch of Academy of Sciences of the USSR,

Institute of Therapy,

Siberian Branch of Medical Sciences of the USSR

Sum mary

The phage $M 13 m p 8$ carring a DNA fragment coding for fusion protein angiogenin $\alpha$ peptide of $\beta$-galactosidase was obtained by oligonucleotide directed mutagenesis technique from the $M 13 m p 8$ phage with a cloned synthetic human angiogenin gene. The synthesis of peptide with $\alpha$-donor activity in the phage M1-1-infected cells was demonstrated. The amount of the fusion protein was estimated at the different stages of $E$. coli cell growth after the phage infection.

\section{СПИСОК ЛИТЕРАТУРЫ}

1. A gene fusion system for generating antibodies against short peptides/B. Löwenadier, B. Jansson, S. Palens et al. // Gene.-1987.-58, N 1.- P. 87-97.

2. Struck D. K., Maratea D., Young $R$. Purification of hybrid $\beta$-galactosidase proteins encoded by $\varphi X 174 E$ lac $Z$ and $E$. coli prlA lacZ: a general method for the isolation of lac $Z$ fusion polypeptides produced in low amounts //J. Mol. and Appl. Genet.1985.-3, N 1.-P. 18-25

3. Патон E. Б., Живолуп A. H. Химерный ген rроC'-lac $Z^{\prime}$ рекомбинантной плазмиды pUC19, сохраняющей $\beta$-галактозидазную активность в клетках Escherichia coli// Биополимеры и клетка.-1987-3, № 5- - С. 276-279.

4. Эксnрессия в Escherichia coli гена лейкоцитарного $\alpha$-2-интерферона человека, трансляционно слитого с $\mathrm{N}$-концевым фрагментом $\beta$-галактозидазы / В. А. Петренко, С. И. Татьков, Л. Н. Семенова и др. // Молекуляр. генетика, микробиология и вирусология.-1988.-4, № 1.-С. $37-41$.

5. Close T. J., Christmann J. L., Rodriquer R. L. M13 bacteriophage and pUC plasmids containing DNA inserts but still capable of $\beta$-galactosidase $\alpha$-complementation // Gene. $-1985-33, \mathrm{~N} 1 .-\mathrm{P} .131-136$

6. Molecular basis of $\beta$-galactosidase $\alpha$-complementation / K. E. Langley, M. R. Villarejo, A. V. Fowler et al. // Proc. Nat. Acad. Sci. USA.- 1975.-72, N 4.-P. 1254.

7. Химико-ферментативньй синтез и клонирование гена ангиогенина человека в составе фага M13mp8 / С. П. Коваленко, В. В. Горн, В. А. Қаргинов и др. // Биоорг. химия.-1988.- 14, № 7.-С. $910-915$.

8. Landon $M$. Cleavage at aspartyl-prolyl bonds // Meth. Enzymol.-1977.-47.P. $145-149$.

9. $E M B O / E M B L$ summer course on site directed mutagenesis: Lab. manual.-- Heidelberg, 1984.-59 p.

10. Sigma Company Chemical Catalog.-1989.-631 p.

11. Миллер Дж. Эксперименты в молекулярной генетике-М. : Мир, 1976- 486 с.

Ин-т биоорг. химии Сиб. отд-ния АН СССР, Новосибирск

Ин-т терапии Сиб. отд-ния АМН СССР, Новосибирск

Получено 23.08 .89 